\title{
Effect of Cr on Aqueous and Atmospheric Corrosion of Automotive Carbon Steel
}

\author{
Sang-won Cho ${ }^{1}{ }^{\circledR}$, Sang-Jin Ko ${ }^{1}$, Jin-Seok Yoo ${ }^{1}$, Yun-Ha Yoo ${ }^{2}$, Yon-Kyun Song ${ }^{2}$ and Jung-Gu Kim ${ }^{1, *}$ \\ 1 Department of Materials Science and Engineering, Sungkyunkwan University, 2066 Seobu-Ro, \\ Jangan-Gu, Suwon-Si 16419, Korea; jsw2811@gmail.com (S.-w.C.); tkdwls121@skku.edu (S.-J.K.); \\ wlstjr5619@skku.edu (J.-S.Y.) \\ 2 POSCO Global R\&D Center, Steel Solution Research Laboratory, 100 Songdogwahak-Ro, \\ Yeonsu-Gu, Incheon 21985, Korea; yunha778@posco.co.kr (Y.-H.Y.); petersong@posco.com (Y.-K.S.) \\ * Correspondence: kimjg@skku.edu
}

check for updates

Citation: Cho, S.-w.; Ko, S.-J.; Yoo, J.-S.; Yoo, Y.-H.; Song, Y.-K.; Kim, J.-G. Effect of $\mathrm{Cr}$ on Aqueous and Atmospheric Corrosion of Automotive Carbon Steel. Materials 2021, 14, 2444. https://doi.org/ $10.3390 /$ ma14092444

Academic Editor: Marián Palcut

Received: 6 April 2021

Accepted: 5 May 2021

Published: 8 May 2021

Publisher's Note: MDPI stays neutral with regard to jurisdictional claims in published maps and institutional affiliations.

Copyright: (c) 2021 by the authors. Licensee MDPI, Basel, Switzerland. This article is an open access article distributed under the terms and conditions of the Creative Commons Attribution (CC BY) license (https:// creativecommons.org/licenses/by/ $4.0 /)$.

\begin{abstract}
This study investigated the effect of $\mathrm{Cr}$ alloying element on the corrosion properties of automotive carbon steel $(0.1 \mathrm{C}, 0.5 \mathrm{Si}, 2.5 \mathrm{Mn}$, Fe Bal., composition given in wt.\%) in aqueous and atmospheric conditions using electrochemical measurement and cyclic corrosion tests. Three steels with $0,0.3$, and $0.5 \mathrm{wt}$.\% Cr were studied by electrochemical impedance spectroscopy. Polarization resistance $\left(R_{p}\right)$ of $0.3 \mathrm{Cr}$ and $0.5 \mathrm{Cr}$ steels was higher than that of $0 \mathrm{Cr}$ steel, and the $\mathrm{R}_{\mathrm{p}}$ also increased as the $\mathrm{Cr}$ content increased. Therefore, $\mathrm{Cr}$ increases the corrosion resistance of automotive carbon steel immersed in a chloride ion $\left(\mathrm{Cl}^{-}\right)$-containing aqueous solution. In the cyclic corrosion test results, $\mathrm{Cl}^{-}$was concentrated at the metal/rust interface in all of the steels regardless of $\mathrm{Cr}$ content. The $\mathrm{Cl}^{-}$was uniformly concentrated and distributed on the $0 \mathrm{Cr}$ steel, but locally and non-uniformly concentrated on the $\mathrm{Cr}$-added steels. The inner rust layer consisted of $\beta-\mathrm{FeOOH}$ containing $\mathrm{Cl}^{-}$and Cr-goethite, while the outer rust layer was composed of amorphous iron oxyhydroxide mixed with various types of rust. $\mathrm{FeCl}_{2}$ and $\mathrm{CrCl}_{3}$ are formed from the $\mathrm{Cl}^{-}$nest developed in the early stage, and the pitting at $\mathrm{CrCl}_{3}$-formed regions are locally accelerated because $\mathrm{Cr}$ is strongly hydrolyzed to a very low $\mathrm{pH}$.
\end{abstract}

Keywords: automotive steel; atmospheric corrosion; electrochemical impedance spectroscopy; cyclic corrosion test; iron oxide

\section{Introduction}

Steel sheets for automobiles are exposed to various corrosive environments due to climate change. In particular, the increased inundation from heavy rain and the use of salt for snow removal accelerate the corrosion of the automobile steel sheet, which leads to the deterioration of the durability and the collision safety of the vehicle [1]. Furthermore, with the recent rapid development of industry, these corrosive environments are becoming more and more severe. Therefore, it is essential to evaluate the corrosion life of the steel for predicting the durability of automobile parts. Currently, corrosion life is most often evaluated by the salt spray test (SST) and cyclic corrosion test (CCT). The accelerated CCT method for simulating an actual environment is used by many automakers. When an automotive carbon steel (ACS) sheet is evaluated through a CCT, atmospheric corrosion occurs on the test specimen and is greatly affected by environmental factors such as the type of material, humidity, time of wetness (TOW), and temperature [2]. For example, in the case of $\mathrm{Cu}$ and $\mathrm{Ag}$, the corrosion rate is most affected by sulfides such as $\mathrm{H}_{2} \mathrm{~S}$ and $\mathrm{SO}_{2}$ in the air, whereas in the case of $\mathrm{Fe}$, acid fumes and fine dust are known to be more important. Furthermore, in coastal cities, the corrosion rate changes depending on the chloride concentration in the air. When the salt particles in the air are adsorbed on the metal surface, water may be condensed on the surface even if the relative humidity is low, which facilitates the formation of a water film [3]. As the TOW lengthens, the corrosion rate increases. 
Generally, weathering steel is widely used to prevent atmospheric corrosion and contains alloying elements such as $\mathrm{Cr}, \mathrm{Cu}$, and Ni. Particularly, $\mathrm{Cr}$ is known as an element that improves the corrosion resistance of low alloy steel in various corrosive environments. When the weathering steel is exposed to a corrosive environment, Fe oxides (porous rust layer) are initially formed under attack from oxygen, similarly to common steel. However, over time, a dense rust layer (protective rust) is formed on the steel surface. This rust layer protects the steel surface, inhibiting corrosion and reducing corrosion rates compared to common steel. In common steel, the oxide rust layer penetrates into the substrate, and corrosion of the substrate continues, while in weathering steel, the amorphous layer enriched with $\mathrm{Cu}, \mathrm{Cr}$, and $\mathrm{Ni}$ inhibits further corrosion progress. Weathering steel forms a thin rust layer with $\mathrm{FeOOH}$ as the main component on the steel surface in the early stages. Then, a Cr-enriched layer (Cr-goethite) with very small particles containing $\mathrm{Cr}$ is formed on the steel surface $[4,5]$. The Cr-goethite layer has cation selectivity, preventing the penetration of corrosion substances such as $\mathrm{SO}_{4}{ }^{2-}$ and $\mathrm{Cl}^{-}$from the outside [6-8]. However, unlike these positive effects, negative effects have also been reported. According to Park et al. [9], in the flue gas desulfurization environment, $\mathrm{Cr}$ induces localized corrosion when $\mathrm{Cr}$ and $\mathrm{Cu}$ are added together in low-carbon steel because $\mathrm{Cr}$ segregates into the grain boundary, forming a $\mathrm{Cr}$ depletion region.

As described above, many research endeavors have been undertaken with respect to $\mathrm{Cr}^{\prime}$ 's effect on the corrosion of metallic materials; however, only a few studies on the effect of $\mathrm{Cr}$ on the corrosion of ACS have been conducted. In this study, the effect of the Cr alloying element on the aqueous corrosion and atmospheric corrosion of ACS was investigated. The aqueous corrosion properties were analyzed using electrochemical measurements in a chloride $\left(\mathrm{Cl}^{-}\right)$-containing solution, and atmospheric corrosion properties were analyzed via a CCT.

\section{Materials and Methods}

The specimens used in the electrochemical test and CCT were ACS containing 0, 0.3, and $0.5 \mathrm{wt} . \% \mathrm{Cr}$ (produced by POSCO, Gwangyang, Korea), as described in Table 1 . The microstructure images of the specimens are shown in Figure 1. In Figure 1, all the steels are composed of ferrite and martensite phases. Most martensite was formed along the grain boundary, with a small amount present inside the ferrite matrix. There is no noticeable difference in the three steels except for the grain size. The higher the $\mathrm{Cr}$ content, the bigger the grain size.

Table 1. Chemical compositions of the specimens (unit: wt.\%).

\begin{tabular}{cccccc}
\hline Steels & Cr & C & Si & Mn & Fe \\
\hline $0 \mathrm{Cr}$ & 0.01 & 0.10 & 0.52 & 2.49 & Bal. \\
$0.3 \mathrm{Cr}$ & 0.32 & 0.10 & 0.52 & 2.49 & Bal. \\
$0.5 \mathrm{Cr}$ & 0.50 & 0.10 & 0.52 & 2.49 & Bal. \\
\hline
\end{tabular}
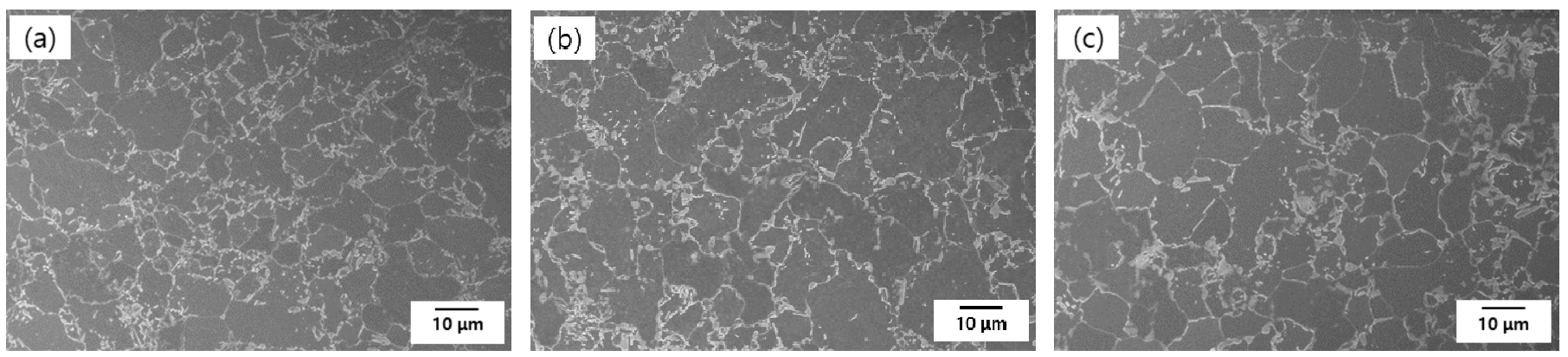

Figure 1. SEM images of the microstructure of (a) $0 \mathrm{Cr}$, (b) $0.3 \mathrm{Cr}$, and (c) $0.5 \mathrm{Cr}$, etched with $2 \%$ nital solution. 
The specimens were cut to a size of $1.5 \mathrm{~cm} \times 1.5 \mathrm{~cm}$, polished with 600-grit $\mathrm{SiC}$ paper, and cleaned with distilled water. Additionally, the solution for electrochemical measurements was $3.5 \mathrm{wt} . \% \mathrm{NaCl}$. All of the electrochemical measurements were conducted in a 3-electrode electrochemical cell. The test specimen was used as the working electrode, a carbon rod was used as the counter electrode, and a saturated calomel electrode was used as the reference electrode. Potentiodynamic polarization tests were performed with a potential sweep of $0.166 \mathrm{mV} / \mathrm{s}$ according to ASTM G5. To establish a stable potential, the scan was initiated after the specimen was stabilized in the solution [10]. Electrochemical impedance spectroscopy (EIS) tests were performed with an amplitude of $10 \mathrm{mV}$ in the frequency range of $100 \mathrm{kHz}$ to $10 \mathrm{mHz}$. Electrochemical tests were conducted by a potentiostat (BioLogics, VMP-2, Seyssinet-Pariset, France). After the CCT, the test specimens were mounted with epoxy and analyzed by an optical microscope (OM), and the components of the corrosion product were analyzed by an electron probe micro-analyzer (EPMA; JEOL, JXA-8530F, Fukuoka, Japan), X-ray diffraction (XRD; Rigaku, D/max-2500V/PC, Tokyo, Japan), and transmission electron microscopy (TEM; FEI, Tecnai F20 G2, Hillsboro, OR, USA).

The specific CCT process is shown in Figure 2. The specimens used for the CCT were cut to a size of $3 \mathrm{~cm} \times 7 \mathrm{~cm}$, and exposed on only one side to the corrosive environment. The CCT was performed for 10, 20, and 30 cycles, respectively. The salt solution used for the CCT was $5 \mathrm{wt} . \% \mathrm{NaCl}$. The length of a CCT cycle was $24 \mathrm{~h}$, consisting of a wet stage for $21 \mathrm{~h}$ and a dry stage at $30 \%$ of relative humidity and $50{ }^{\circ} \mathrm{C}$ for $3 \mathrm{~h}$.

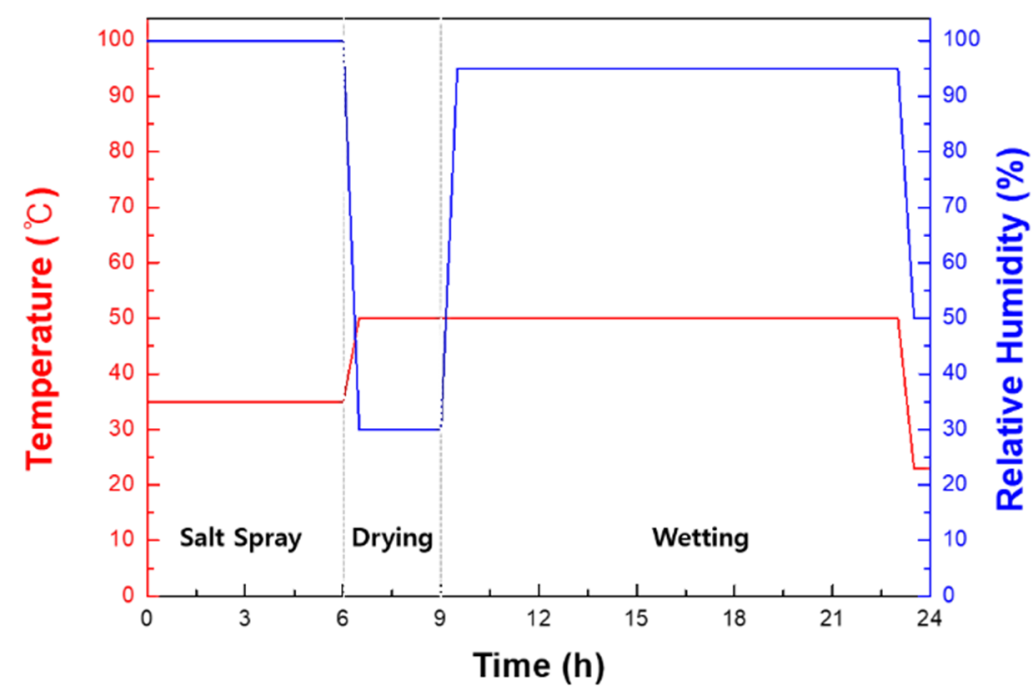

Figure 2. Specific conditions for the cyclic corrosion test.

\section{Results and Discussion}

\subsection{Electrochemical Measurement}

Potentiodynamic polarization tests were conducted to analyze the difference in corrosion characteristics depending on the $\mathrm{Cr}$ content, and the results are shown in Figure 3 and Table 2. In Figure 3, all of the specimens show an active corrosion behavior that increases with increasing potential in $\mathrm{Cl}^{-}$-containing environments without passivation. Additionally, there was no significant difference in the corrosion potential regardless of the $\mathrm{Cr}$ content. The corrosion potential $\left(\mathrm{E}_{\mathrm{corr}}\right)$ and corrosion current density of $0.5 \mathrm{Cr}$ steel were slightly lower than that of $0 \mathrm{Cr}$ and $0.3 \mathrm{Cr}$ steels, but this is an insignificant difference that can be regarded as an experimental error. 


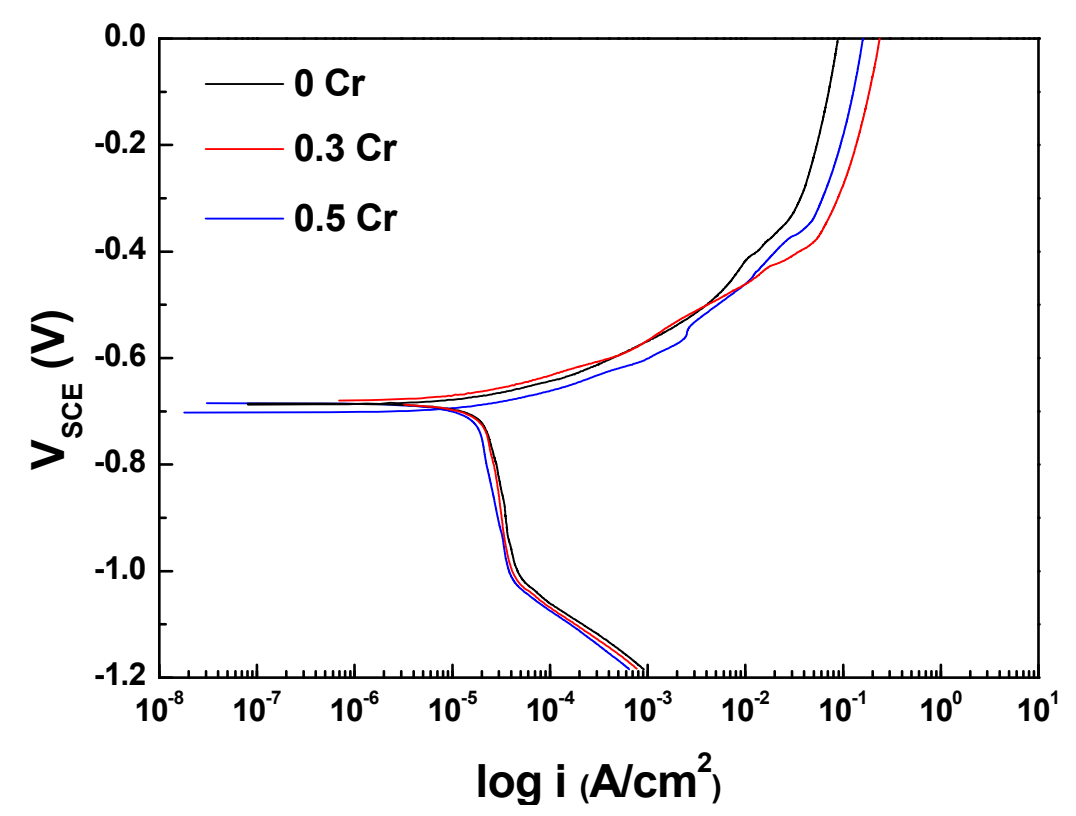

Figure 3. Potentiodynamic polarization curves in $3.5 \mathrm{wt} . \% \mathrm{NaCl}$ solution.

Table 2. Potentiodynamic polarization test results in $3.5 \mathrm{wt} . \% \mathrm{NaCl}$ solution.

\begin{tabular}{cccc}
\hline Parameter & $\mathbf{0 ~ C r}$ & $\mathbf{0 . 3} \mathbf{C r}$ & $\mathbf{0 . 5} \mathbf{C r}$ \\
\hline $\mathrm{E}_{\mathrm{corr}}\left(\mathrm{mV}_{\mathrm{SCE}}\right)$ & $-686.5 \pm 1.4$ & $-683.6 \pm 5.4$ & $-693.2 \pm 12.6$ \\
$\mathrm{I}_{\mathrm{corr}}\left(\mu \mathrm{A} / \mathrm{cm}^{2}\right)$ & 21.3 & 20.2 & 17.4 \\
\hline
\end{tabular}

In order to obtain a better understanding of the effect of $\mathrm{Cr}$ on the corrosion behavior of ACS under aqueous conditions, EIS measurement was performed in a $3.5 \mathrm{wt} . \% \mathrm{NaCl}$ solution at room temperature. Figure 4 shows the results of EIS measurement in the form of Nyquist and Bode plots under open circuit potential (OCP) according to various immersion times. The Nyquist plots were not perfect semicircles due to dispersion effects that are often caused by the geometrical inhomogeneity or non-uniform current distribution on the electrode surface [11]. The capacitive loops in the high- and low-frequency regions overlapped. The capacitive loop of the high-frequency region showed the resistance of the film, whereas that of the low-frequency region showed the charge transfer resistance [12-14]. In the $0 \mathrm{Cr}$ steel, the size of the semicircle for $1 \mathrm{~h}$ was larger than that for $0 \mathrm{~h}$, and then became smaller with respect to immersion time. This means that a thin and weak oxide layer was formed on the steel surface at the initial stage of the corrosion process, and deteriorated with respect to immersion time due to its instability [15]. Similar to $0 \mathrm{Cr}$ steel, the size of the semicircles for the $0.3 \mathrm{Cr}$ and $0.5 \mathrm{Cr}$ steels also increased immediately after immersion, and then decreased with immersion time. However, the size of the overall capacitive semicircles is ordered as $0.5 \mathrm{Cr}>0.3 \mathrm{Cr}>0 \mathrm{Cr}$. In general, the size of the capacitive semicircle on the Nyquist plot represents corrosion resistance. This means that the $\mathrm{Cr}$ alloying element within $0.5 \mathrm{wt}$ \% improves corrosion resistance in an aqueous environment. In the Bode plots, the impedance at a low frequency and the shoulder width at the phase angle were increased and wider immediately after immersion, and then decreased and narrower with immersion time. This result is consistent with the Nyquist impedance interpretation. 

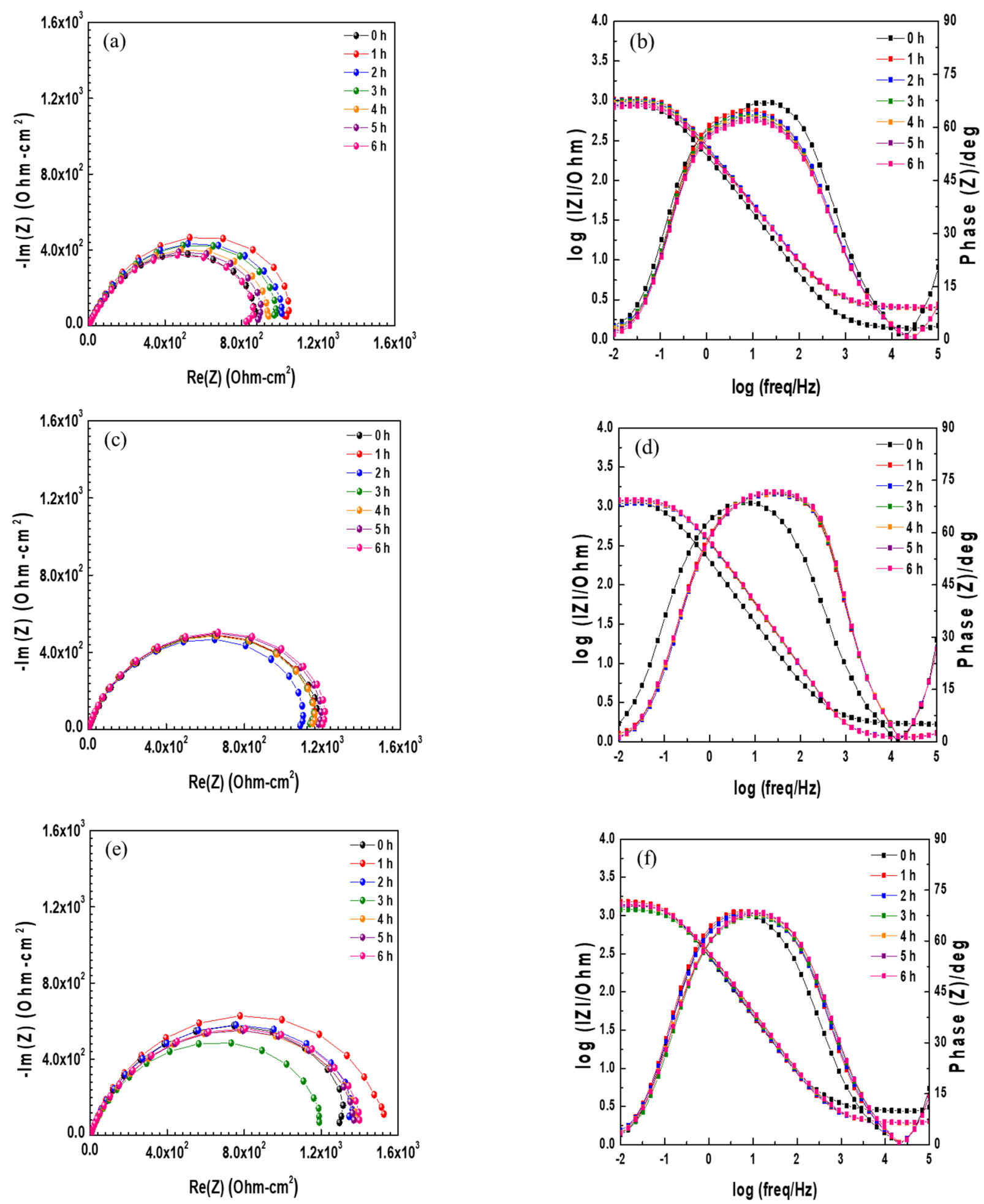

Figure 4. Nyquist and Bode impedance plots of EIS data of $(\mathbf{a}, \mathbf{b}) 0 \mathrm{Cr}$ steel, (c,d) $0.3 \mathrm{Cr}$ steel, and (e,f) $0.5 \mathrm{Cr}$ steel in 3.5 wt.\% $\mathrm{NaCl}$ solution.

To determine the optimized values for the resistance and capacitance parameters, the equivalent circuit was used as shown in Figure $5 . R_{s}$ is the test solution resistance, $R_{\text {film }}$ is the oxide film resistance, $R_{c t}$ is the charge transfer resistance, and $R_{\text {film }}+R_{c t}$ is total resistance or polarization resistance $\left(R_{p}\right)$, which is proportional to the radius of the capacitive loop in the Nyquist plot. The constant phase element (CPE) is the capacitive response of the system. CPE1 is the capacitive response of the oxide film, and CPE2 is 
the capacitive response of the double layer caused by the dissolution of the metal and the charge separation between the metal/electrolyte interface [16-19]. In the equivalent circuit, CPE is defined as below:

$$
\mathrm{Z}_{\mathrm{CPE}}=\mathrm{Q}_{0}^{-1}(\mathrm{j} \omega)^{-\mathrm{n}}
$$

where $\mathrm{Z}$ is the impedance, $\mathrm{Q}_{0}$ is the coefficient of proportionality, $\mathrm{j}$ is the imaginary number, $\omega$ is the angular frequency, and $n$ is the empirical CPE exponent $(0 \leq n \leq 1)$ measuring the deviation from the behavior of an ideal electric capacity $[20,21]$. CPE can represent resistance $(n=0)$, capacitance $(n=1)$, inductance $(n=-1)$, or Warburg impedance $(n=0.5)$ in accordance with $n$ [22].

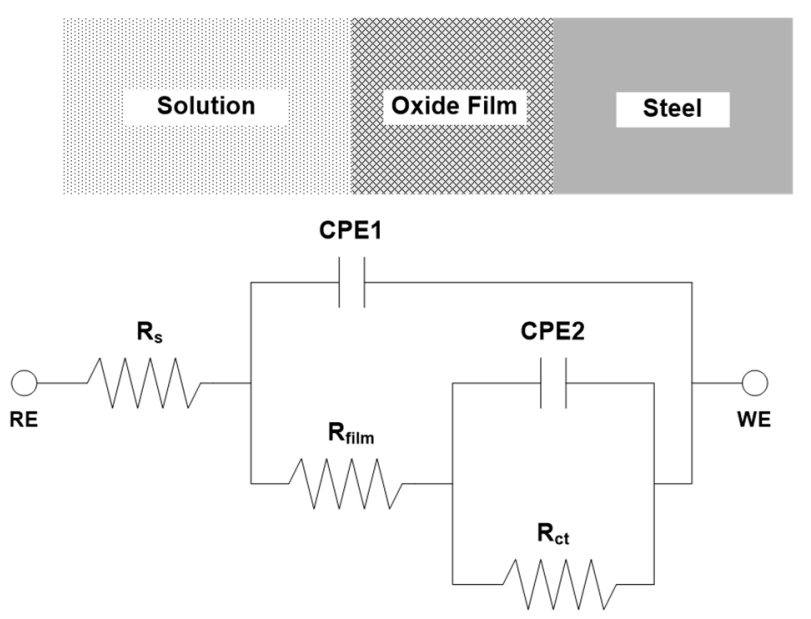

Figure 5. Equivalent circuit for ACS in $3.5 \mathrm{wt} . \% \mathrm{NaCl}$ solution.

The EIS data were fitted using the ZSimpWin (Princeton Applied Research, Oak Ridge, TN, USA) program and the results are shown in Table 3 . The $\mathrm{R}_{\mathrm{p}}$ of $0.3 \mathrm{Cr}$ and $0.5 \mathrm{Cr}$ steels was higher than that of $0 \mathrm{Cr}$ steel, and the $\mathrm{R}_{\mathrm{p}}$ also increased as the $\mathrm{Cr}$ content increased. This indicates that the corrosion resistance is increased as the $\mathrm{Cr}$ content increases. This is believed to be due to the bigger grain size of the steel with higher $\mathrm{Cr}$ content. Metal with active polarization behavior decreases the corrosion rate with bigger grain size [23]. Therefore, Cr improved the corrosion resistance of the ACS that was immersed in the $\mathrm{Cl}^{-}$-containing aqueous solution.

Table 3. Parameters from electrochemical impedance spectroscopy measurements.

\begin{tabular}{|c|c|c|c|c|c|c|c|c|c|}
\hline \multirow[b]{2}{*}{ Steel } & \multirow[b]{2}{*}{$\begin{array}{c}\text { Immersion } \\
\text { Time }\end{array}$} & \multirow[b]{2}{*}{$\begin{array}{c}R_{s} \\
\left(\Omega \cdot \mathrm{cm}^{-2}\right)\end{array}$} & \multicolumn{2}{|c|}{ CPE1 } & \multirow[b]{2}{*}{$\underset{\left(\Omega \cdot \mathrm{cm}^{-2}\right)}{R_{\text {film }}}$} & \multicolumn{2}{|c|}{ CPE2 } & \multirow[b]{2}{*}{$\begin{array}{c}R_{\mathrm{ct}} \\
\left(\Omega \cdot \mathrm{cm}^{-2}\right)\end{array}$} & \multirow[b]{2}{*}{$\begin{array}{c}R_{p} \\
\left(\Omega \cdot \mathrm{cm}^{-2}\right)\end{array}$} \\
\hline & & & $\begin{array}{c}Q_{\text {film }} \\
\left(\Omega^{-1}\right. \\
\left.\mathrm{cm}^{-2} \cdot \mathrm{s}^{\mathrm{n}}\right)\end{array}$ & $n_{1}$ & & $\begin{array}{c}Q_{\mathrm{ct}} \\
\left(\Omega^{-1}\right. \\
\left.\mathrm{cm}^{-2} \cdot \mathbf{s}^{\mathrm{n}}\right)\end{array}$ & $n_{1}$ & & \\
\hline \multirow{7}{*}{$0 \mathrm{Cr}$} & $0 \mathrm{~h}$ & 1.424 & $7.52 \times 10^{-4}$ & 0.8355 & 29.9 & $3.97 \times 10^{-4}$ & 0.9671 & 636.5 & 665.7 \\
\hline & $1 \mathrm{~h}$ & 2.531 & $6.11 \times 10^{-4}$ & 0.8146 & 192.6 & $1.29 \times 10^{-4}$ & 0.9516 & 951.6 & 1144.2 \\
\hline & $2 \mathrm{~h}$ & 2.522 & $6.36 \times 10^{-4}$ & 0.8037 & 294 & $1.48 \times 10^{-4}$ & 0.9883 & 801.2 & 1095.2 \\
\hline & $3 \mathrm{~h}$ & 2.542 & $6.65 \times 10^{-4}$ & 0.801 & 239.9 & $1.55 \times 10^{-4}$ & 0.9724 & 831.3 & 1071.2 \\
\hline & $4 \mathrm{~h}$ & 2.549 & $6.84 \times 10^{-4}$ & 0.796 & 267.4 & $1.61 \times 10^{-4}$ & 0.997 & 752.1 & 1019.5 \\
\hline & $5 \mathrm{~h}$ & 2.574 & $6.72 \times 10^{-4}$ & 0.7959 & 217.5 & $1.73 \times 10^{-4}$ & 0.9593 & 766.3 & 983.8 \\
\hline & $6 \mathrm{~h}$ & 2.589 & $6.81 \times 10^{-4}$ & 0.7953 & 203.7 & $1.85 \times 10^{-4}$ & 0.9509 & 733.1 & 936.8 \\
\hline \multirow{7}{*}{$0.3 \mathrm{Cr}$} & $0 \mathrm{~h}$ & 1.773 & $1.71 \times 10^{-4}$ & 1 & 3 & $9.06 \times 10^{-4}$ & 0.7621 & 1304 & 1307 \\
\hline & $1 \mathrm{~h}$ & 1.227 & $2.05 \times 10^{-4}$ & 0.9653 & 32.3 & $3.76 \times 10^{-4}$ & 0.7516 & 1210 & 1242.3 \\
\hline & $2 \mathrm{~h}$ & 1.22 & $1.92 \times 10^{-4}$ & 0.9714 & 29.2 & $3.79 \times 10^{-4}$ & 0.7541 & 1151 & 1180.2 \\
\hline & $3 \mathrm{~h}$ & 1.212 & $1.83 \times 10^{-4}$ & 0.9759 & 26.5 & $3.90 \times 10^{-4}$ & 0.7497 & 1215 & 1241.5 \\
\hline & $4 \mathrm{~h}$ & 1.212 & $1.69 \times 10^{-4}$ & 0.9843 & 24.3 & $4.00 \times 10^{-4}$ & 0.7475 & 1223 & 1247.3 \\
\hline & $5 \mathrm{~h}$ & 1.217 & $1.59 \times 10^{-4}$ & 0.9914 & 23.7 & $4.10 \times 10^{-4}$ & 0.7442 & 1266 & 1289.7 \\
\hline & $6 \mathrm{~h}$ & 1.215 & $1.57 \times 10^{-4}$ & 0.993 & 23.1 & $4.08 \times 10^{-4}$ & 0.7424 & 1285 & 1308.1 \\
\hline
\end{tabular}


Table 3. Cont.

\begin{tabular}{|c|c|c|c|c|c|c|c|c|c|}
\hline \multirow[b]{2}{*}{ Steel } & \multirow[b]{2}{*}{$\begin{array}{l}\text { Immersion } \\
\text { Time }\end{array}$} & \multirow[b]{2}{*}{$\begin{array}{c}R_{s} \\
\left(\Omega \cdot \mathrm{cm}^{-2}\right)\end{array}$} & \multicolumn{2}{|c|}{ CPE1 } & \multirow[b]{2}{*}{$\begin{array}{c}R_{\text {film }} \\
\left(\Omega \cdot \mathrm{cm}^{-2}\right)\end{array}$} & \multicolumn{2}{|c|}{ CPE2 } & \multirow[b]{2}{*}{$\begin{array}{c}R_{\mathrm{ct}} \\
\left(\Omega \cdot \mathrm{cm}^{-2}\right)\end{array}$} & \multirow[b]{2}{*}{$\begin{array}{c}R_{p} \\
\left(\Omega \cdot \mathrm{cm}^{-2}\right)\end{array}$} \\
\hline & & & $\begin{array}{c}Q_{\text {film }} \\
\left(\Omega^{-1}\right. \\
\left.\mathrm{cm}^{-2} \cdot \mathbf{s}^{\mathrm{n}}\right)\end{array}$ & $n_{1}$ & & $\begin{array}{c}Q_{\mathrm{ct}} \\
\left(\Omega^{-1}\right. \\
\left.\mathrm{cm}^{-2} \cdot \mathbf{s}^{\mathrm{n}}\right)\end{array}$ & $n_{1}$ & & \\
\hline \multirow{7}{*}{$0.5 \mathrm{Cr}$} & $0 \mathrm{~h}$ & 2.809 & $4.71 \times 10^{-4}$ & 0.8449 & 21.6 & $2.14 \times 10^{-4}$ & 0.8069 & 1414 & 1435.6 \\
\hline & $1 \mathrm{~h}$ & 1.986 & $5.09 \times 10^{-4}$ & 0.8474 & 59 & $1.63 \times 10^{-4}$ & 0.7983 & 1543 & 1602 \\
\hline & $2 \mathrm{~h}$ & 1.978 & $5.18 \times 10^{-4}$ & 0.8405 & 63.5 & $1.67 \times 10^{-4}$ & 0.7818 & 1419 & 1482.5 \\
\hline & $3 \mathrm{~h}$ & 1.964 & $3.86 \times 10^{-4}$ & 0.8637 & 20.6 & $2.95 \times 10^{-4}$ & 0.7261 & 1270 & 1290.6 \\
\hline & $4 \mathrm{~h}$ & 1.963 & $3.24 \times 10^{-4}$ & 0.8782 & 14.9 & $3.39 \times 10^{-4}$ & 0.7095 & 1489 & 1503.9 \\
\hline & $5 \mathrm{~h}$ & 2.001 & $1.18 \times 10^{-4}$ & 0.9798 & 4.5 & $5.31 \times 10^{-4}$ & 0.7418 & 1502 & 1506.5 \\
\hline & $6 \mathrm{~h}$ & 2.013 & $9.42 \times 10^{-4}$ & 0.9999 & 3.6 & $5.44 \times 10^{-4}$ & 0.748 & 1542 & 1545.6 \\
\hline
\end{tabular}

\subsection{Cyclic Corrosion Test Results}

The specimens after the CCT were cut and the cross-section was observed with an $\mathrm{OM}$ and the results are shown in Figure 6. After 10 cycles, the rust of all steels was thin and relatively uniform. However, after 20 cycles, brown and black oxides were formed on the inner layer and outer layer, respectively. Especially after 30 cycles, the amount of corrosion product of $0.3 \mathrm{Cr}$ and $0.5 \mathrm{Cr}$ steels was greater than that of $0 \mathrm{Cr}$ steel, and corroded in a more localized way. Furthermore, since the thickness of the oxide layer is proportional to the amount of corrosion of the base metal, a thick oxide layer was locally formed on the $0.3 \mathrm{Cr}$ and $0.5 \mathrm{Cr}$ steels.
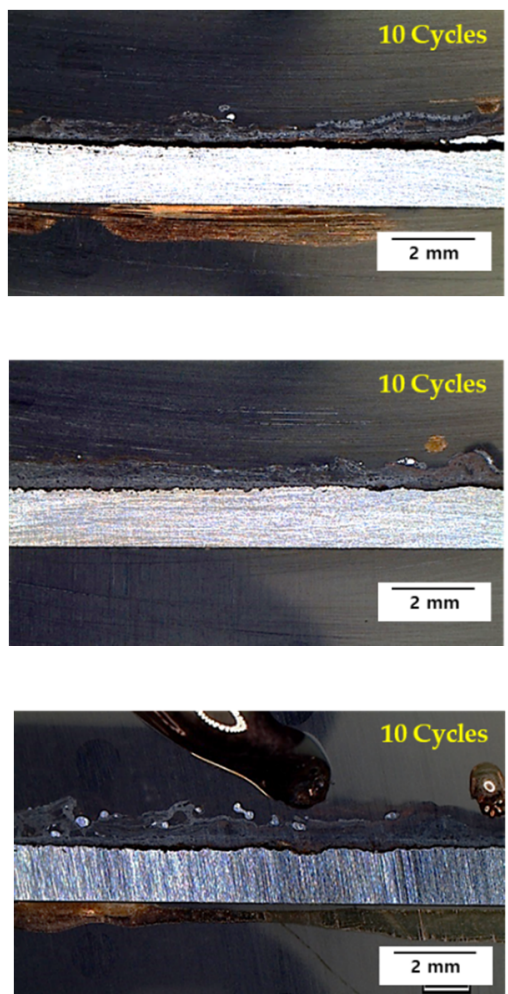

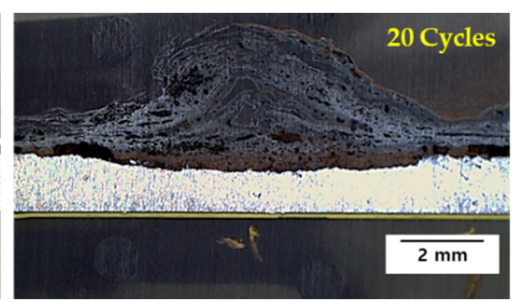

(a)

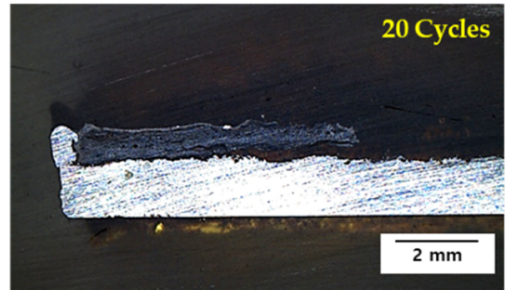

(b)
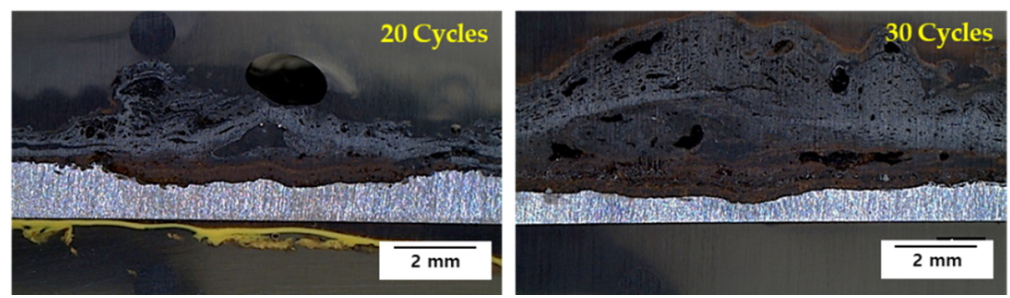

(c)

Figure 6. Cross-section OM images of (a) 0 Cr steel, (b) $0.3 \mathrm{Cr}$ steel, and (c) $0.5 \mathrm{Cr}$ steel after CCT.

To determine the localized corrosion tendency, the pitting factor (PF) with a concept similar to that given in ASTM G46 was used. A PF value of 1 means perfect uniform corrosion, and a higher PF means an increased localized corrosion tendency. The PF 
for each CCT cycle was derived by the following equation, and the variation of the PF according to CCT cycle is shown in Figure 7.

$$
\mathrm{PF}=\frac{\mathrm{p}}{\mathrm{d}}
$$

where $\mathrm{p}$ is the maximum penetration depth, and $\mathrm{d}$ is the average penetration depth.

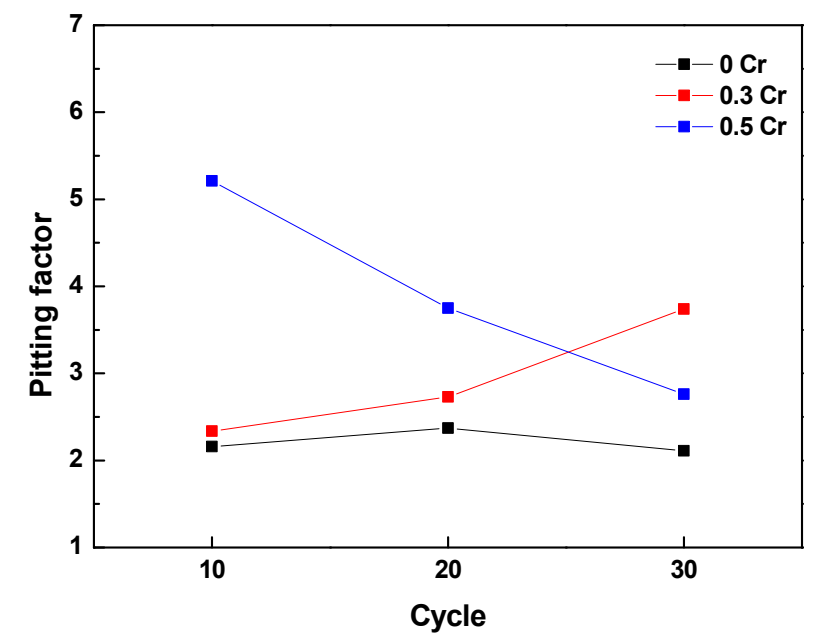

Figure 7. Variation of pitting factor according to CCT cycle.

In the case of $0 \mathrm{Cr}$ steel, the PF was approximately 2 regardless of the cycle, while the $\mathrm{PF}$ of $0.3 \mathrm{Cr}$ and $0.5 \mathrm{Cr}$ steels changed depending on the cycle. In all cycles, the PF of the $\mathrm{Cr}$-added steels was higher than that of the $0 \mathrm{Cr}$ steel, but the PF was not proportional to $\mathrm{Cr}$ content. This indicates that the $\mathrm{Cr}$ alloying element can accelerate localized corrosion, and the presence or absence of $\mathrm{Cr}$ greatly affects the localized corrosion, not the $\mathrm{Cr}$ content.

The cross-section of the specimen after 10 and 30 cycles was analyzed to determine the chemical composition using EPMA, and the results are shown in Figure 8. The rust layer of $0 \mathrm{Cr}$ steel was composed entirely of porous iron oxide (e.g., $\gamma-\mathrm{FeOOH}, \gamma-\mathrm{Fe}_{2} \mathrm{O}_{3}, \mathrm{Fe}_{3} \mathrm{O}_{4}$ ). In addition, $\mathrm{Cl}^{-}$was accumulated at the metal/rust interface and on the inner layer with uniform concentration and distribution. The $\mathrm{Cr}$-added steels had a very dense and uniform Cr-enriched region in the inner rust layer, while the outer rust layer was composed of porous iron oxide, like $0 \mathrm{Cr}^{-\mathrm{Cl}^{-}}$was detected underneath the $\mathrm{Cr}$-enriched layer and at the metal/rust interface, but unlike $0 \mathrm{Cr}$ steel, it was localized and non-uniformly concentrated. The rust layer of the 30-cycle steel was exfoliated from the metal, and the $\mathrm{Cl}^{-}$concentration in the inner rust layer was increased significantly compared to 10 cycles. Therefore, it is considered that the corrosion is accelerated because the protective oxide layer loses its protective property after the rust layer exfoliates.

To summarize the above results, $\mathrm{Cl}^{-}$was concentrated at the metal/rust interface in all of the specimens regardless of $\mathrm{Cr}$ content. Generally, since the localized corrosion in an atmospheric environment is caused by $\mathrm{Cl}^{-}$enrichment $[4,24]$, localized corrosion with a PF of approximately 2 or higher occurred in all of the steels, as shown in Figure 7. However, $0.3 \mathrm{Cr}$ and $0.5 \mathrm{Cr}$ steels had higher PFs than $0 \mathrm{Cr}$ steel because $\mathrm{Cl}^{-}$was localized and non-uniformly concentrated as compared with $0 \mathrm{Cr}$ steel. 
(a)
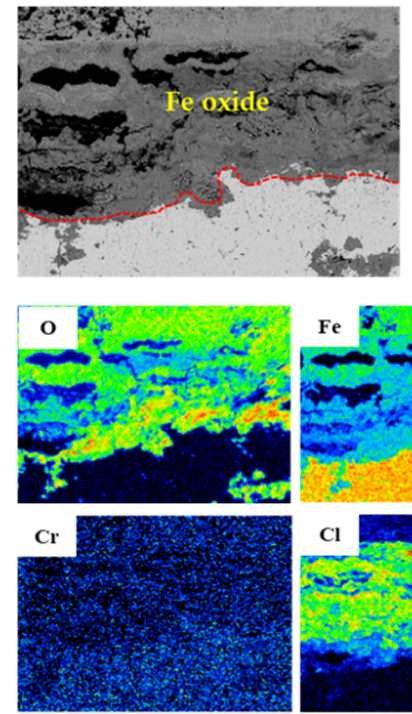

(b)
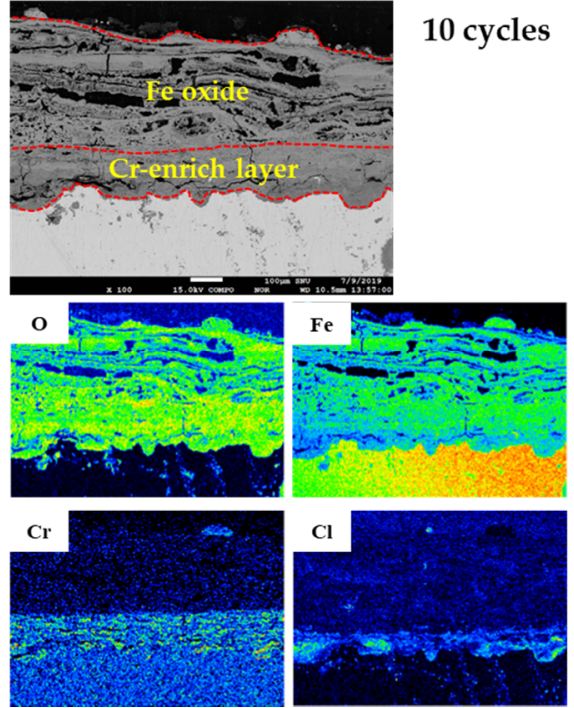

(c)
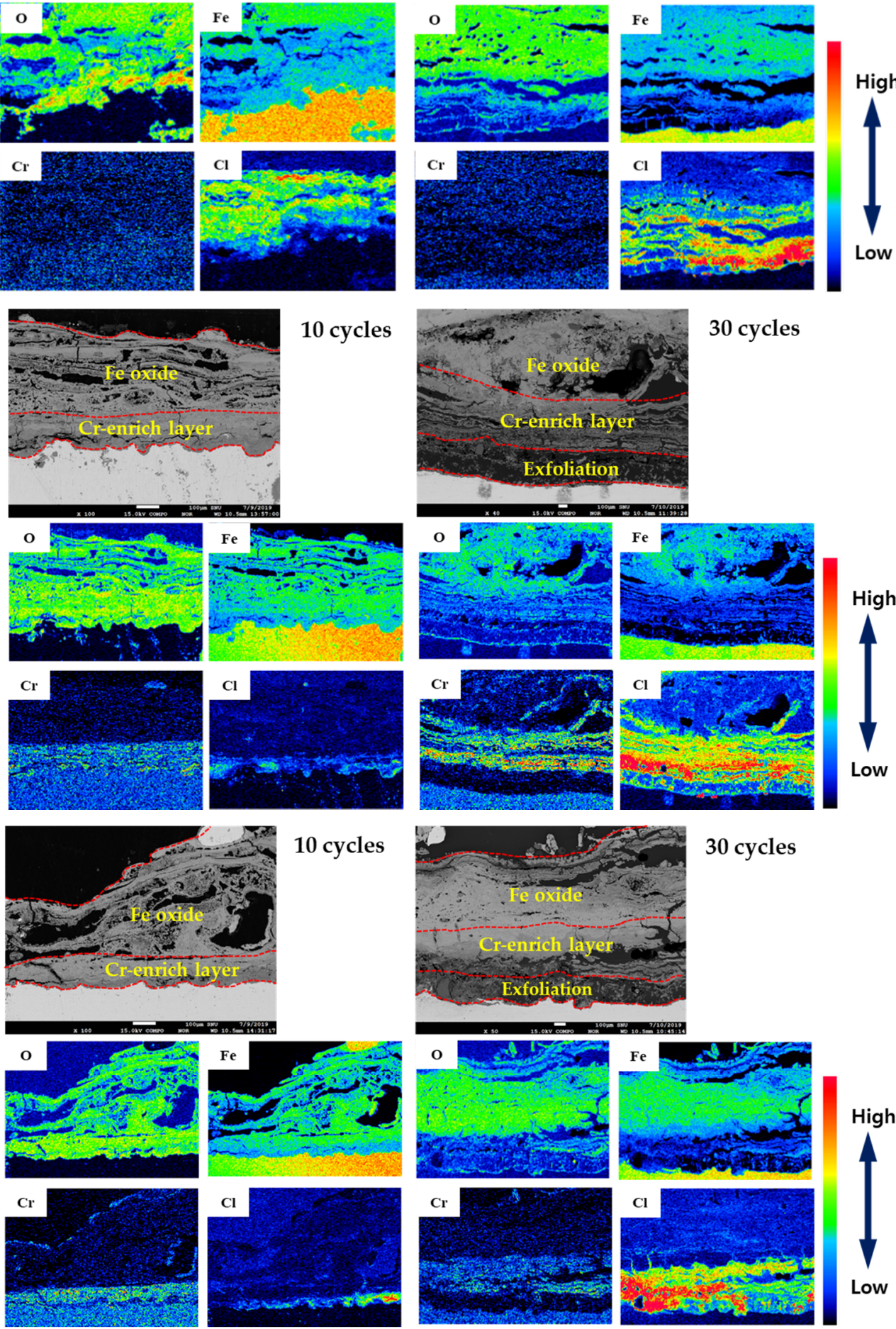

High
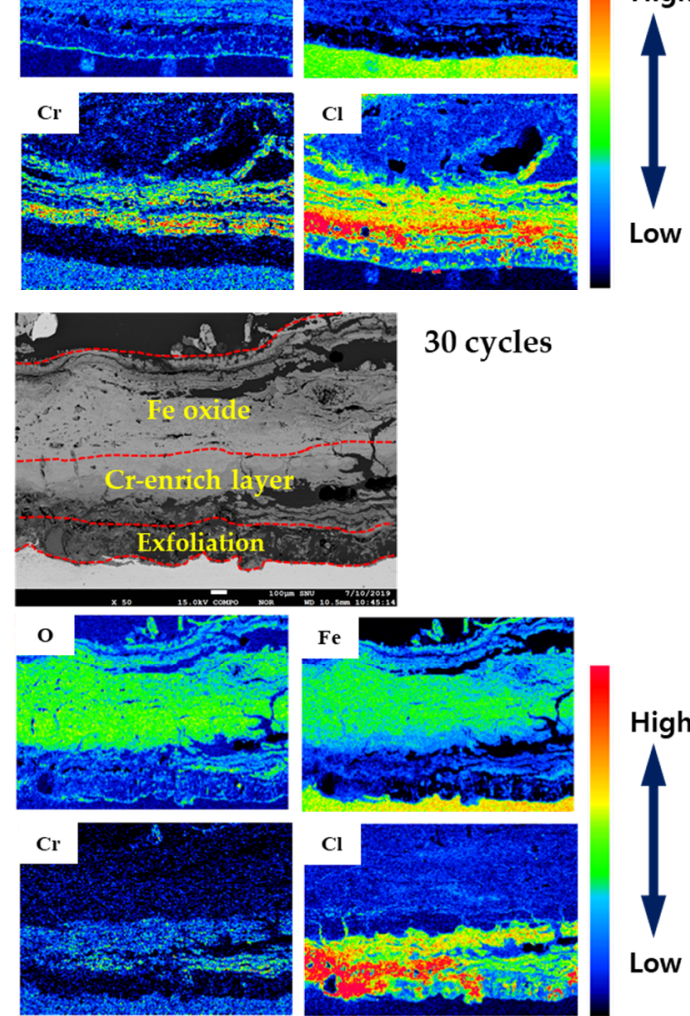

30 cycles

Figure 8. EPMA analysis of (a) $0 \mathrm{Cr}$ steel, (b) $0.3 \mathrm{Cr}$ steel, and (c) $0.5 \mathrm{Cr}$ steel after CCT. 


\subsection{Rust Constituent Analysis}

The constituent of the rust formed after the CCT was analyzed by XRD, EDS, and TEM, and the results are shown in Figures 9 and 10. As shown in Figure 9, the phase of rust formed by the CCT was almost the same for all steels. The rusts were composed of various oxides and hydroxides such as $\alpha-\mathrm{FeOOH}$ (goethite), $\beta-\mathrm{FeOOH}$ (akaganeite), $\gamma-\mathrm{FeOOH}$ (lepidocrocite), $\gamma-\mathrm{Fe}_{2} \mathrm{O}_{3}$ (maghemite), and $\mathrm{Fe}_{3} \mathrm{O}_{4}$ (magnetite). Among them, akaganeite always contains $\mathrm{Cl}^{-}$in the lattice because it is stabilized by the $\mathrm{Cl}^{-}$entering the lattice structure. In addition, akaganeite is formed only during the dry stage in an atmospheric environment, and $\mathrm{Cl}^{-}$in the akaganeite is dissolved in water to promote corrosion during the wet stage. That is, the akaganeite acts as a $\mathrm{Cl}^{-}$reservoir. As a result, a large amount of akaganeite is formed inside the pit generated by atmospheric corrosion [3,6,24-26]. Therefore, akaganeite was formed in the inner rust layer, and $\mathrm{Cl}^{-}$was observed at the metal/rust interface, as shown in Figure 8.

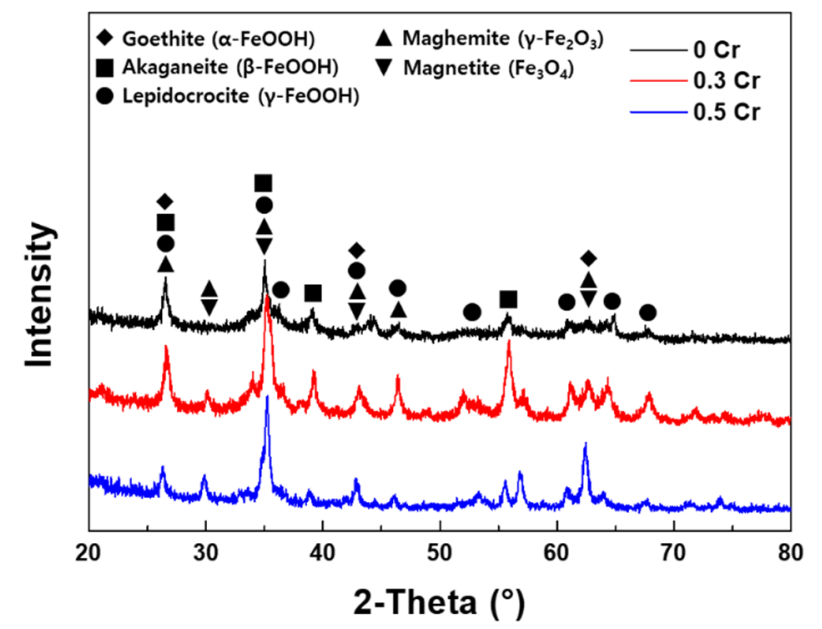

Figure 9. XRD analysis of the specimen surfaces after 20 cycles of CCT.

The EDS results, TEM images, and diffraction patterns of the inner and outer rust formed on the $0.5 \mathrm{Cr}$ steel were analyzed, and the results are shown in Figure 10. Chlorine was observed in the inner rust particle as an acicular single crystal with a size of about $100 \mathrm{~nm}$, as shown in Figure 10a. This is the major characteristic of akaganeite [27]. In Figure $10 \mathrm{~b}, \mathrm{Cr}$ and $\mathrm{Cl}^{-}$were observed together in the inner rust particle. The particle was polycrystalline and was a spherical agglomeration with a size of several nanometers. As the spherical-shaped rust is the main feature of goethite [28], the particle is $\mathrm{Cr}$-containing nanoscale goethite (Cr-goethite). Since dissolved or enriched $\mathrm{Cr}$ suppresses the growth of goethite crystals [7], the size of the Cr-goethite particles is very small. Cr-goethite is so small in size that it acts as a protective film that is densely formed in the inner rust layer. Furthermore, $\mathrm{Cr}$-goethite has cation selectivity so it can inhibit the penetration of aggressive anions such as $\mathrm{Cl}^{-}$and $\mathrm{SO}_{4}{ }^{2-}$ and improve corrosion resistance [7,25,29-31]. In short, $\mathrm{Cr}$-goethite was formed in the inner rust layer of $\mathrm{Cr}$-added steels, which blocked the inflow of additional $\mathrm{Cl}^{-}$from the outside and consequently improved the corrosion resistance. As shown in Figure 10c, $\mathrm{Cl}^{-}$and $\mathrm{Cr}$ were not detected in the outer rust particle. Therefore, the outer rust layer is composed of various rusts such as lepidocrocite, maghemite, and magnetite detected from the XRD analysis results. In summary, the inner rust layer consists of akaganeite containing $\mathrm{Cl}^{-}$and $\mathrm{Cr}$-goethite, while the outer rust layer is composed of amorphous iron oxyhydroxide mixed with various types of rust. 
(a)
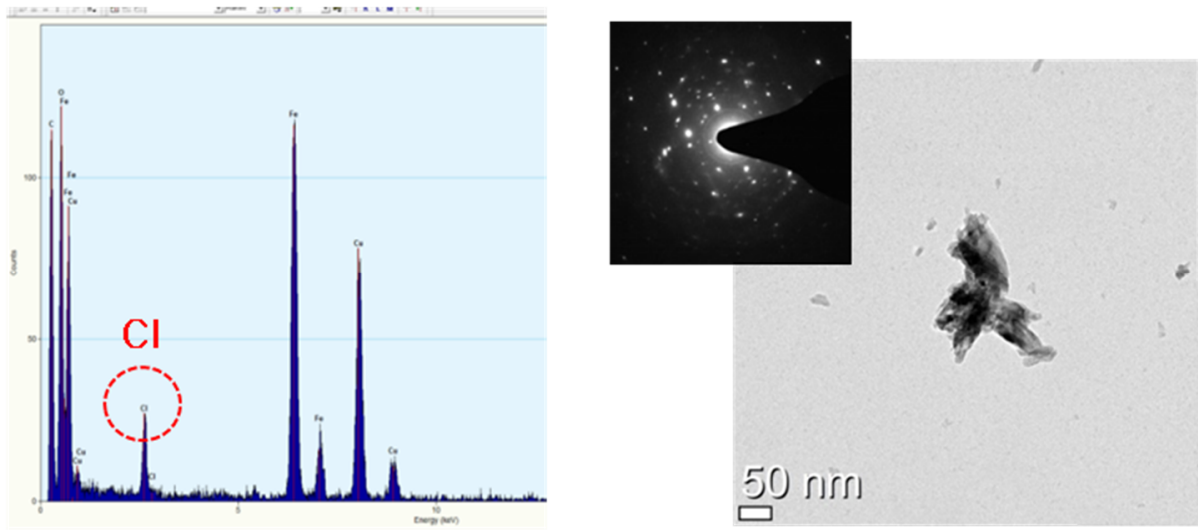

(b)
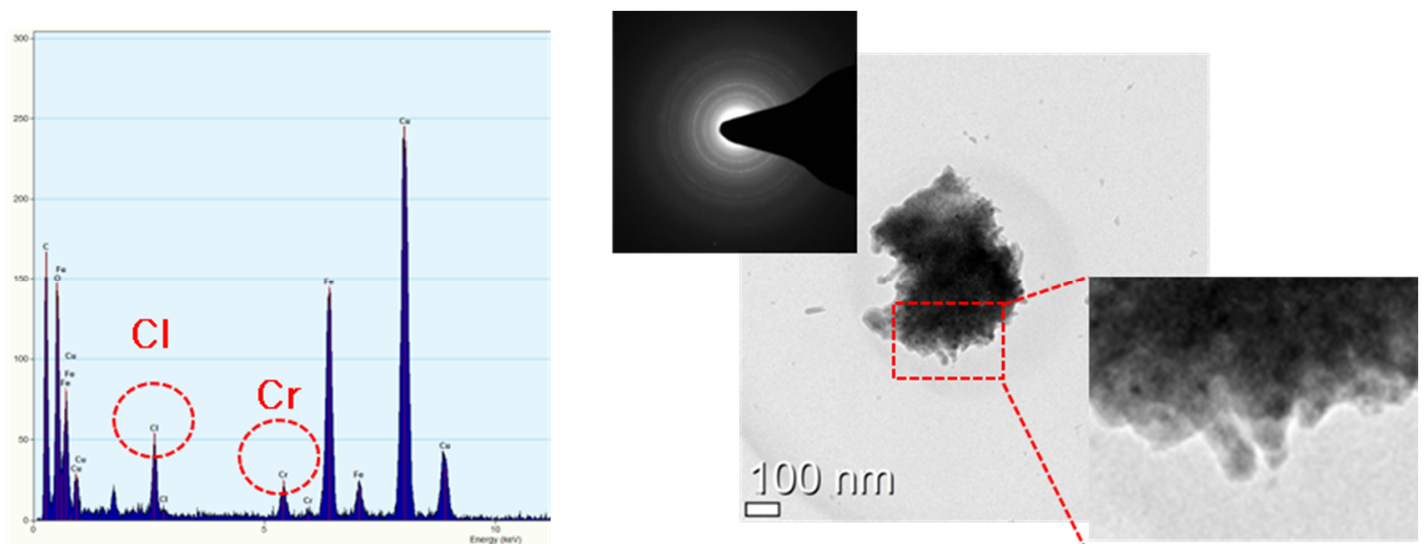

(c)
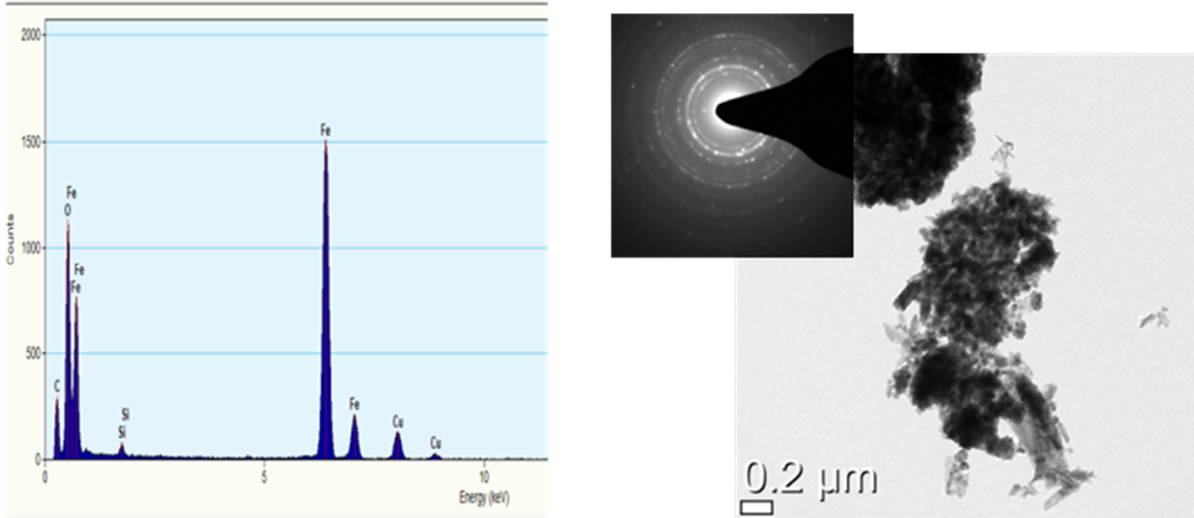

Figure 10. TEM images and the diffraction patterns of $(\mathbf{a}, \mathbf{b})$ inner rust and (c) outer rust formed on the $0.5 \mathrm{Cr}$ steel.

\subsection{Localized Corrosion Mechanism of Cr-Added Steel under Wet/Dry Conditions}

The $\mathrm{Cr}$ alloying element accelerates localized corrosion under Cl-containing wet/dry conditions unlike the immersion condition. The mechanism of localized corrosion of $\mathrm{Cr}$ added steel under wet/dry conditions is as follows, and a schematic diagram is shown in Figure 11. 


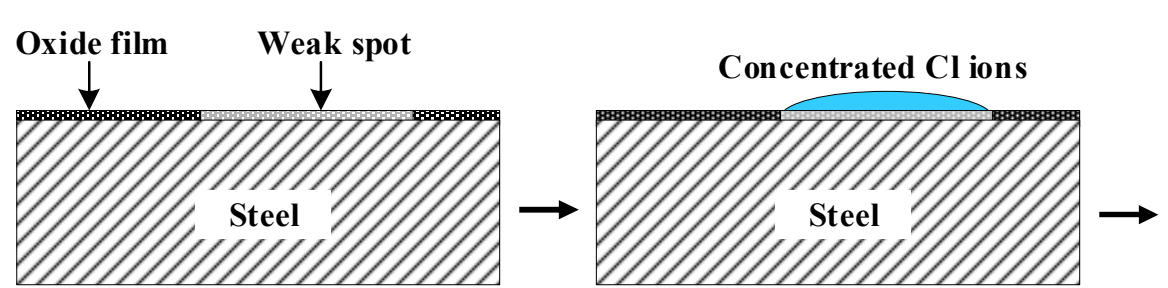

Formation of $\mathrm{Cl}^{-}$nest

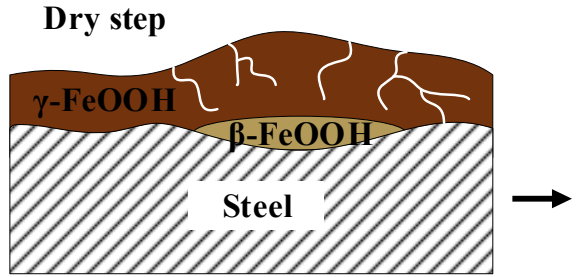

Formation of $\beta$-FeOOH

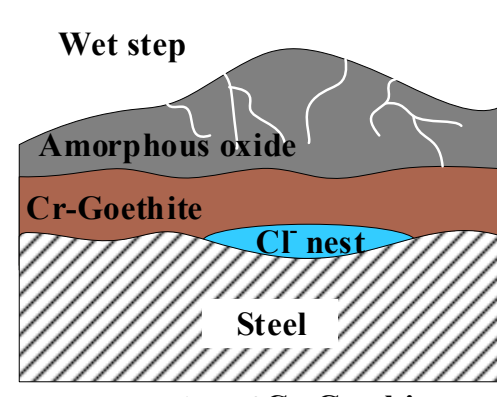

Formation of Cr-Goethite

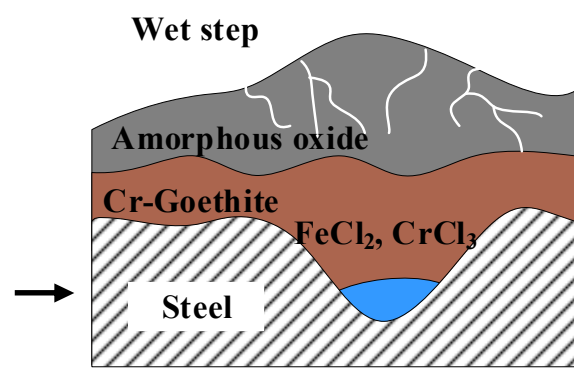

Localized pH drop by hydrolysis reaction of $\mathrm{Fe}$ and $\mathrm{Cr}$ with $\mathrm{Cl}^{-}$

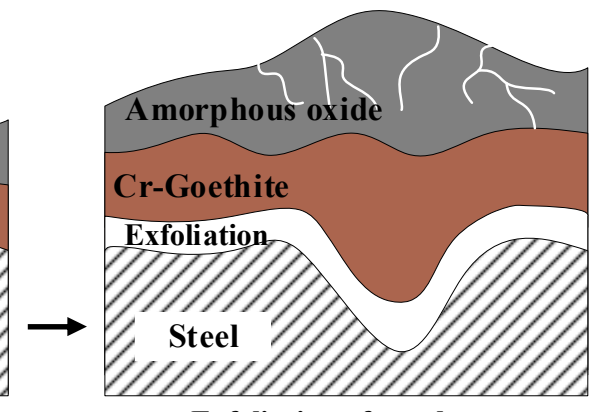

Exfoliation of rust layer

Figure 11. Schematic diagram of the mechanism of localized corrosion of Cr-added steel under wet/dry conditions.

Corrosion of steel begins in areas where the inherent oxide film is weak. During the wet stage, $\mathrm{Cl}^{-}$ions existing in the aqueous adsorption layer move to these weak areas, and a Cl-concentrated region (nest) is formed [32]. The $\mathrm{Cl}^{-}$is adsorbed on the steel surface, and then atmospheric corrosion initiates. Thereafter, $\mathrm{Fe}^{2+}$ reacts with $\mathrm{H}_{2} \mathrm{O}$ to form $\mathrm{Fe}(\mathrm{OH})_{2}$, and with salt or $\mathrm{Cl}^{-}$in the air to form $\mathrm{FeCl}_{2}$.

$$
\begin{gathered}
\mathrm{Fe} \rightarrow \mathrm{Fe}^{2+}+2 \mathrm{e}^{-} \\
\mathrm{Fe}^{2+}+2 \mathrm{H}_{2} \mathrm{O} \rightarrow \mathrm{Fe}(\mathrm{OH})_{2}+2 \mathrm{H}^{+} \\
\mathrm{Fe}^{2+}+2 \mathrm{Cl}^{-} \rightarrow \mathrm{FeCl}_{2}
\end{gathered}
$$

During the dry stage, $\mathrm{Fe}(\mathrm{OH})_{2}$ is transformed into lepidocrocite, and $\mathrm{FeCl}_{2}$ formed in the $\mathrm{Cl}$-concentrated region is transformed into akaganeite. After that, lepidocrocite and akaganeite are reduced to amorphous oxide or magnetite in the wet stage. Next, magnetite is re-oxidized into lepidocrocite.

$$
\begin{gathered}
2 \gamma-\mathrm{FeOOH}+\mathrm{Fe}^{2+} \rightarrow \mathrm{Fe}_{3} \mathrm{O}_{4}+2 \mathrm{H}^{+} \\
\mathrm{Fe}_{3} \mathrm{O}_{4}+3 / 2 \mathrm{O}_{2}+\mathrm{H}_{2} \mathrm{O} \rightarrow 3 \gamma-\mathrm{FeOOH}
\end{gathered}
$$

In the atmospheric rusting process, lepidocrocite on the steel surface transforms into amorphous ferric hydroxide, then it converts to goethite. $\mathrm{Cl}^{-}$may facilitate this reaction and promote goethite formation [33-35].

$$
\begin{gathered}
\gamma-\mathrm{FeOOH} \rightarrow \mathrm{FeO}_{\mathrm{x}}(\mathrm{OH})_{3-2 \mathrm{x}} \text { (amorphous ferric oxyhydroxide) } \rightarrow \alpha-\mathrm{FeOOH} \\
\gamma-\mathrm{FeOOH} \rightarrow \mathrm{FeO}_{x}(\mathrm{OH})_{2-2 x} \mathrm{Cl} \rightarrow \alpha-\mathrm{FeOOH}+\mathrm{HCl}
\end{gathered}
$$

$\mathrm{Cr}^{3+}$ ions dissolved in the early stages of the corrosion process are more easily deposited as hydroxides near the steel surface compared to the $\mathrm{Fe}^{2+}$ ions since the solubility of $\mathrm{Fe}^{2+}$ ions is higher than that of $\mathrm{Cr}^{3+}$. Additionally, the $\mathrm{Cr}^{3+}$ ions act as nuclei for the growth of Cr-goethite. Finally, an ultrafine $\mathrm{Cr}$-goethite layer is formed in the inner rust layer when the wet/dry process is repeated [6]. Since Cr-goethite has cation selectivity, it suppresses the penetration of aggressive anions and improves corrosion resistance. Then, 
after the formation of Cr-goethite, the inflow of extra $\mathrm{Cl}^{-}$from the outside is blocked, so that $\mathrm{Cl}^{-}$is locally accumulated underneath the $\mathrm{Cr}$-enriched layer.

During the wet stage, $\mathrm{Cl}^{-}$ions in the akaganeite formed in the inner rust layer are dissolved and eluted in water, resulting in the formation of $\mathrm{FeCl}_{2}$ and $\mathrm{CrCl}_{3}$. The hydrolysis reactions of these $\mathrm{Fe}$ and $\mathrm{Cr}$ salts occur.

$$
\begin{aligned}
& \mathrm{FeCl}_{2}+2 \mathrm{H}_{2} \mathrm{O} \rightarrow \mathrm{Fe}(\mathrm{OH})_{2}+2 \mathrm{HCl} \\
& \mathrm{CrCl}_{3}+3 \mathrm{H}_{2} \mathrm{O} \rightarrow \mathrm{Cr}(\mathrm{OH})_{3}+3 \mathrm{HCl}
\end{aligned}
$$

The $\mathrm{pH}$ of the steel surface is reduced by the hydrolysis reaction of Fe and $\mathrm{Cr}[36,37]$. Since $\mathrm{Cr}$ tends to strongly hydrolyze up to $\mathrm{pH} 1.4$, it enhances the susceptibility to localized corrosion compared to the hydrolysis reaction of $\mathrm{Fe}$ [38]. That is, $\mathrm{FeCl}_{2}$ and $\mathrm{CrCl}_{3}$ are formed from the $\mathrm{Cl}^{-}$nest developed in the early stage, and the $\mathrm{CrCl}_{3}$-formed regions are locally accelerated. Even if $\mathrm{Cr}$ is not added, $\mathrm{Cl}^{-}$may cause localized corrosion. However, when $\mathrm{Cr}$ is added, localized corrosion is more accelerated since $\mathrm{Cr}$ is strongly hydrolyzed to a very low $\mathrm{pH}$.

Finally, when the wet/dry cycle is continuously repeated, the rust layer is exfoliated and loses its protective property. Then, $\mathrm{Cl}^{-}$easily penetrates into the gap between the separated rust layer and substrate, which accelerates the localized corrosion of ACS.

\section{Conclusions}

In this study, the effect of Cr alloying element on the corrosion properties of ACS in aqueous and atmospheric conditions was investigated using electrochemical measurements and a CCT. The conclusions based on the investigations are as follows:

- In the electrochemical measurement results, the $\mathrm{Cr}$ alloying element improves the corrosion resistance of the ACS that was immersed in the Cl-containing aqueous solution.

- $\mathrm{Cl}$ is concentrated at the metal/rust interface in all of the specimens regardless of $\mathrm{Cr}$ content after the CCT. The $\mathrm{Cl}$ is uniformly concentrated and distributed on the $0 \mathrm{Cr}$ steel, whereas $\mathrm{Cl}$ is localized and non-uniformly concentrated on the $\mathrm{Cr}$-added steels. The PF of the Cr-added steels is higher than that of the $0 \mathrm{Cr}$ steel during the CCT.

- The inner rust layer consists of $\mathrm{Cl}$-containing akaganeite and $\mathrm{Cr}$-goethite, while the outer rust layer is composed of amorphous iron oxyhydroxide mixed with various types of rust.

- $\mathrm{FeCl}_{2}$ and $\mathrm{CrCl}_{3}$ are formed from the $\mathrm{Cl}$ nest developed in the early stage, and the pitting at $\mathrm{CrCl}_{3}$-formed regions is locally accelerated because $\mathrm{Cr}$ is strongly hydrolyzed to a very low $\mathrm{pH}$.

Author Contributions: Conceptualization, S.-w.C. and Y.-H.Y.; Data curation, S.-w.C.; Formal analysis, S.-w.C.; Funding acquisition, J.-G.K.; Investigation, S.-w.C., S.-J.K., and J.-G.K.; Methodology, J.-G.K.; Project administration, Y.-H.Y., Y.-K.S., and J.-G.K.; Resources, Y.-H.Y. and Y.-K.S.; Software, S.-J.K. and J.-S.Y.; Validation, Y.-H.Y. and J.-G.K.; Visualization, S.-w.C.; Writing-original draft, S.-w.C.; Writing—review and editing, S.-w.C., S.-J.K., J.-S.Y., Y.-H.Y., Y.-K.S., and J.-G.K. All authors have read and agreed to the published version of the manuscript.

Funding: This research was funded by POSCO, grant number $2018 Z 098$.

Institutional Review Board Statement: Not applicable.

Informed Consent Statement: Not applicable.

Conflicts of Interest: The authors declare no conflict of interest.

\section{References}

1. Lee, C.; Kang, B.; Choi, B.-H.; Lee, J.; Lee, K. Observation and characterization of squeak noises of polymeric materials for automotive interior parts under field-degradation. Trans. KSAE 2017, 25, 257-265. [CrossRef]

2. Adikari, A.; Munasinghe, R.D.S.; Jayatileke, S. Prediction of atmospheric corrosion-A Review. Engineer $2014,47,75-83$. [CrossRef] 
3. Alcántara, J.; Chico, B.; Simancas, J.; Díaz, I.; Morcillo, M. Marine atmospheric corrosion of carbon steel: A review. Materials 2017, 10, 406. [CrossRef]

4. Kamimura, T.; Stratmann, M. The influence of chromium on the atmospheric corrosion of steel. Corros. Sci. 2001, 43, 429-447. [CrossRef]

5. Asami, K.; Kikuchi, M. Characterization of rust layers on weathering steels air-exposed for a long period. Mater. Trans. 2002, 43, 2818-2825. [CrossRef]

6. Yamashita, M.; Shimizu, T.; Konishi, H.; Mizuki, J.; Uchida, H. Structure and protective performance of atmospheric corrosion product of $\mathrm{Fe}-\mathrm{Cr}$ alloy film analyzed by Mössbauer spectroscopy and with synchrotron radiation X-rays. Corros. Sci. 2003, 45, 381-394. [CrossRef]

7. Yamashita, M.; Miyuki, H.; Matsuda, Y.; Nagano, H.; Misawa, T. The long term growth of the protective rust layer formed on weathering steel by atmospheric corrosion during a quarter of a century. Corros. Sci. 1994, 36, 283-299. [CrossRef]

8. Zhao, Q.-H.; Liu, W.; Zhu, Y.-C.; Zhang, B.-L.; Li, S.-Z.; Lu, M.-X. Effect of small content of chromium on wet-dry acid corrosion behavior of low alloy steel. Acta Metall. Sin-Engl. 2017, 30, 164-175. [CrossRef]

9. Park, S.-A.; Kim, J.-G.; Lee, B.-H.; Yoon, J.-B. Development of sulfuric and hydrochloric acid dew-point corrosion-resistant steels: 1. Effect of alloying elements on the corrosion resistance of low-alloy steels. Korean J. Met. Mater. 2014, 52, 837-855.

10. Kim, S.-H.; Lee, J.-H.; Kim, J.-G.; Kim, W.-C. Effect of the crevice former on the corrosion behavior of 316L stainless steel in chloride-containing synthetic tap water. Met. Mater. Int. 2018, 24, 516-524. [CrossRef]

11. Cheng, Q.; Chen, Z. The cause analysis of the incomplete semi-circle observed in high frequency region of EIS obtained from TEL-covered pure copper. Int. J. Electrochem. Sci 2013, 8, 8282-8290.

12. Keddam, M.; Mottos, O.R.; Takenouti, H. Reaction model for iron dissolution studied by electrode impedance: I. Experimental results and reaction model. J. Electrochem. Soc. 1981, 128, 257-266. [CrossRef]

13. Liu, W.; Dou, J.; Lu, S.; Zhang, P.; Zhao, Q. Effect of silty sand in formation water on $\mathrm{CO}_{2}$ corrosion behavior of carbon steel. Appl. Surf. Sci. 2016, 367, 438-448. [CrossRef]

14. Zeng, L.; Zhang, G.; Guo, X. Erosion-corrosion at different locations of X65 carbon steel elbow. Corros. Sci. 2014, 85, 318-330. [CrossRef]

15. Srinivasan, A.; Blawert, C.; Huang, Y.; Mendis, C.; Kainer, K.; Hort, N. Corrosion behavior of Mg-Gd-Zn based alloys in aqueous $\mathrm{NaCl}$ solution. J. Magnes. Alloy 2014, 2, 245-256. [CrossRef]

16. Kim, M.; Jang, S.; Woo, S.; Kim, J.; Kim, Y. Corrosion resistance of ferritic stainless steel in exhaust condensed water containing aluminum cations. Corrosion 2015, 71, 285-291. [CrossRef]

17. Cho, S.; An, J.-H.; Lee, S.-H.; Kim, J.-G. Effect of pH on the passive film characteristics of lean duplex stainless steel in chloridecontaining synthetic tap water. Int. J. Electrochem. Sci 2020, 15, 4406-4420. [CrossRef]

18. Chen, Y.; Hong, T.; Gopal, M.; Jepson, W. EIS studies of a corrosion inhibitor behavior under multiphase flow conditions. Corros. Sci. 2000, 42, 979-990. [CrossRef]

19. Hamdy, A.S.; El-Shenawy, E.; El-Bitar, T. Electrochemical impedance spectroscopy study of the corrosion behavior of some niobium bearing stainless steels in 3.5\% NaCl. Int. J. Electrochem. Sci. 2006, 1, 171-180.

20. Bentiss, F.; Lebrini, M.; Vezin, H.; Chai, F.; Traisnel, M.; Lagrené, M. Enhanced corrosion resistance of carbon steel in normal sulfuric acid medium by some macrocyclic polyether compounds containing a 1,3,4-thiadiazole moiety: AC impedance and computational studies. Corros. Sci. 2009, 51, 2165-2173. [CrossRef]

21. Lopez, D.A.; Simison, S.; De Sanchez, S. The influence of steel microstructure on $\mathrm{CO}_{2}$ corrosion. EIS studies on the inhibition efficiency of benzimidazole. Electrochim. Acta 2003, 48, 845-854. [CrossRef]

22. Mansfeld, F. Recording and analysis of AC impedance data for corrosion studies. Corrosion 1981, 37, 301-307. [CrossRef]

23. Ralston, K.D.; Birbilis, N.; Davies, C.H.J. Revealing the relationship between grain size and corrosion rate of metals. Scripta Mater. 2010, 63.12, 1201-1204. [CrossRef]

24. Xiao, H.; Ye, W.; Song, X.; Ma, Y.; Li, Y. Evolution of akaganeite in rust layers formed on steel submitted to wet/dry cyclic tests. Materials 2017, 10, 1262-1275. [CrossRef] [PubMed]

25. Asami, K.; Kikuchi, M. In-depth distribution of rusts on a plain carbon steel and weathering steels exposed to coastal-industrial atmosphere for 17 years. Corros. Sci. 2003, 45, 2671-2688. [CrossRef]

26. Alcántara, J.; Chico, B.; Díaz, I.; De la Fuente, D.; Morcillo, M. Airborne chloride deposit and its effect on marine atmospheric corrosion of mild steel. Corros. Sci. 2015, 97, 74-88. [CrossRef]

27. Senthilnathan, A.; Dissanayake, D.; Chandrakumara, G.; Mantilaka, M.; Rajapakse, R.; Pitawala, H.; Nalin de Silva, K. Akaganeite nanorices deposited muscovite mica surfaces as sunlight active green photocatalyst. $R$. Soc. Open Sci. 2019, 6, 1-12. [CrossRef] [PubMed]

28. Verma, S.; Baig, R.N.; Nadagouda, M.N.; Varma, R.S. Oxidative CH activation of amines using protuberant lychee-like goethite. Sci. Rep. 2018, 8, 1-7. [CrossRef] [PubMed]

29. Kimura, M.; Kihira, H. Nanoscopic mechanism of protective-rusts formation on weathering steel surfaces. SHINNITTETSU GIHO 2004, 91, 77-81.

30. Xu, Q.; Gao, K.; Lv, W.; Pang, X. Effects of alloyed Cr and Cu on the corrosion behavior of low-alloy steel in a simulated groundwater solution. Corros. Sci. 2016, 102, 114-124. [CrossRef] 
31. Melchers, R.E. Effect of small compositional changes on marine immersion corrosion of low alloy steels. Corros. Sci. 2004, 46, 1669-1691. [CrossRef]

32. Henriksen, J. The distribution of $\mathrm{NaCl}$ on Fe during atmospheric corrosion. Corros. Sci. 1969, 9, 573-576. [CrossRef]

33. Ma, Y.; Li, Y.; Wang, F. Corrosion of low carbon steel in atmospheric environments of different chloride content. Corros. Sci. 2009, 51, 997-1006. [CrossRef]

34. Ma, Y.; Li, Y.; Wang, F. The effect of $\beta-\mathrm{FeOOH}$ on the corrosion behavior of low carbon steel exposed in tropic marine environment. Mater. Chem. Phys. 2008, 112, 844-852. [CrossRef]

35. Misawa, T.; Hashimoto, K.; Shimodaira, S. The mechanism of formation of iron oxide and oxyhydroxides in aqueous solutions at room temperature. Corros. Sci. 1974, 14, 131-149. [CrossRef]

36. Yang, W.; Ni, R.-C.; Hua, H.-Z.; Pourbaix, A. The behavior of chromium and molybdenum in the propagation process of localized corrosion of steels. Corros. Sci. 1984, 24, 691-707. [CrossRef]

37. SA, P.; DP, L. Alloying effect of chromium on the corrosion behavior of low-alloy steels. Meter. Trans. 2013, 54, 1770-1778.

38. Jones, D.A. Principles and Prevention of Corrosion, 2nd ed.; Prentice Hall, Inc.: Upper Saddle River, NJ, USA, 1996 ; p. 217. 